\title{
Utilization of Wallostonite/ Quasi Isotropic S2 Glass Fiber Doped in to Epoxy on Mechanical and Thermal Properties
}

\author{
D. Madhava Reddy ${ }^{1}$, C. H. Rakesh ${ }^{1}$, N. Karthikeyan ${ }^{1, *}$, M. Ashok Kumar ${ }^{2}$, \\ G. Nagaraju ${ }^{3}$ \\ ${ }^{1}$ Department of Mechanical Engineering, Kasireddy Narayanreddy College of Engineering and \\ Research, Abdullapurmet, Hayath Nagar, Hyderabad, Ranga Reddy, India \\ ${ }^{2}$ Department of Mechanical Engineering, Dr. KV Subbareddy Engineering College, Kurnool, India \\ ${ }^{3}$ Department of Electronics \& Communication Engineering, Gates Institute of Technology, \\ Gooty, Anantapuramu, India \\ *E-mail address: nadadurkarthik@gmail.com
}

\begin{abstract}
Study focused on the performance of injection moulded short Wallostonite filler and chopped glass fiber reinforced hybrid epoxy composites. Results showed that hybridization of glass fiber and Wallostonite was found to be comparable to that of epoxy glass fiber composites. Analysis of fiber length distribution in the composite and fracture surface was performed to study fiber breakage fracture mechanism. The simultaneous compounding of epoxy with two fillers was done to obtain a hybrid composite. The mechanical properties of hybrid, injection molded, chopped glass fiber/ Wallostonite/epoxy composites have been investigated by considering the effect of hybridization by these two fillers. This system is expected to have considerable mechanical properties. It has been found that the tensile, flexural, and impact properties of the filled epoxy were higher than those of unfilled epoxy. The hybrid effects of the tensile strength and modulus were studied by the rule of hybrid mixtures (RoHM) using the values of single fiber composites.
\end{abstract}

Keywords: Epoxy; Wallostonite; S2 glass fiber; characterization; DSC; TGA

\section{INTRODUCTION}

The need of development of new materials to meet the challenges for innovative applications in the scientific and technological fields has become a very much essential in the recent days. The present conventional materials are unable to fulfill all the conditions and the requirements such as higher strength, heat distortion temperature and light weight with low cost. In order to achieve the above requirements an attempt has been made in the technology to find a novel material called 'Composite' whose constituents will act synergistically to solve the need of the applications. As we cross the threshold into the 'Composite material age', it becomes increasingly important to understand the properties, performance, cost and potential of the composites. Composite is one such material, which has revolutionized the concept of high strength. A wide range of particulate materials are used in the composites. These new 
advanced materials with specific properties have led to the development of better cheaper polymer composites. The natural fibers like coconut fiber, banana fiber, sisal fiber, sansevaeria cylindrica fiber, sugarcane fiber etc. which is having low density with good strength can be used as reinforcing agent to strengthen the composite [1-20]. Not only the natural fiber but also sometimes synthetic fibers like various types of Glass fiber, Almond fiber, Carbon fibers which is having high strength with low density can also be used as reinforcing agents. Any powdered material can also be used as fillers. The most commonly used fillers are various grades of $\mathrm{CaCO}_{3}$, talc, various types of silica, talc, Graphite, Montmorillonite clay (nano size) etc now recently Wallostonite powder is used as filler and S2 Glass fiber as reinforcing agent.

S2-Glass fiber (alumino silicate glass without $\mathrm{CaO}$, whereas high $\mathrm{MgO}$ content with high tensile strength) with is a light weight (density $2.43 \mathrm{~g} / \mathrm{cm}^{3}$ ), extremely strong and robust material. The Tensile strength of S2 glass material is $4890 \mathrm{MPa}$, compressive strength is 1600 $\mathrm{MPa}$. Although the strength properties are somewhat lower than carbon fiber, it is less expensive. Its bulk strength and weight properties are also very favorable when compared to metals, and it can be easily formed during molding process. The plastic matrix may be epoxy, a thermosetting plastic (most often polyester or vinylester) or thermoplastic [21-30].

Wallostonite is calcium in silicate mineral $\left(\mathrm{CaSiO}_{3}\right)$ that may contain small amounts of iron, magnesium, and manganese substituting for calcium. It is usually white. It forms when impure lime stone or dolostone is subjected to high temperature and pressure some times in the presence of silica-bearing fluid as skarns or contact metamorphic rocks. Associated minerals include garnets, vesuvianite, diopside, tremolite, epidote, plagioclase feld spar, pyroxene and calcite. Some of the properties that make Wallostonite so useful are its high brightness and whiteness, low moisture and oil absorption, and low volatile content. Wallostonite is used primarily in ceramics, friction products (brakes and clutches), metal making, paint filler and plastics. In our current work Wallostonite is chosen as natural filler in the second composition [31-42].

In the present work, epoxy polymer matrix was filled with Wallostonite mineral filler and same was reinforced with quasi-isotropic S2 glass fiber used for preparing the epoxy hybrid composites. After the composite been prepared, its performance was evaluated by means of mechanical and thermal properties. Tensile, flexural, impact and DSC and TGA properties are tested and optimized.

\section{MATERIALS}

In the present work commercially available Epoxy (Thermosetting plastic), S2 glass fiber and Wallostonite powder is used.

S2-Glass fiber ( alumino silicate glass without $\mathrm{CaO}$ but high $\mathrm{MgO}$ content with high tensile strength) with is a light weight (density $2.43 \mathrm{~g} / \mathrm{cm}^{3}$ ), extremely strong and robust material. The Tensile strength of S2 glass material is $4890 \mathrm{MPa}$, compressive strength is 1600 $\mathrm{MPa}$. Although the strength properties are somewhat lower than carbon fiber, it is less expensive. Its bulk strength and weight properties are also very favorable when compared to metals, and it can be easily formed during molding process. The plastic matrix may be epoxy, a thermosetting plastic (most often polyester or vinylester) or thermoplastic.

Wallostonite is calcium in silicate mineral $\left(\mathrm{CaSiO}_{3}\right)$ that may contain small amounts of iron, magnesium, and manganese substituting for calcium. It is usually white. It forms when impure lime stone or dolostone is subjected to high temperature and pressure some times in 
the presence of silica-bearing fluid as skarns or contact metamorphic rocks. Associated minerals include garnets, vesuvianite, diopside, tremolite, epidote, plagioclase feld spar, pyroxene and calcite.

\section{1. Preparation of Composites}

The Wallostonite powder in the ratio of (1gm, $2 \mathrm{gm}, 3 \mathrm{gm}, 4 \mathrm{gm} \& 5 \mathrm{gm})$ is mixed separately in the epoxy resin of $50 \mathrm{gm}$ weight. The $2 \mathrm{gm}$ wt of S2 glass fiber is placed randomly in the mould $\left(300 \times 300 \times 3 \mathrm{~mm}^{3}\right)$ and the mixture of epoxy with different weight ratios of Wallostonite along with the hardener (catalyst) is injected into the mould using Injection moulding apparatus. The mixture of epoxy, Wallostonite and hardener is stirred well using ultra sonic sonicator. The composites are cured at room temperature for 24 hours.

\section{2. Mechanical tests}

Tests for determining tensile and flexural properties were conducted on computer controlled Instron 4301 type universal testing machine. For tensile test, standard dumbbell specimen were maintained from cast sheet and tested according to ASTM D 638. The cross head speed was $50 \mathrm{~mm} / \mathrm{min}$. Flexural properties were determined by three point bending method as per ASTM D 790. The test speed was maintained between 1.3 to $1.5 \mathrm{~mm} / \mathrm{min}$. Izod impact strength was determined using Izod Charpy digital impact tester, as per ASTM D 256. Shore D hardness test was conducted according to ASTM D 2240. A minimum of five specimens were tested in each case to obtain average value.

\section{3. Thermal Properties}

Thermogravimetric analysis (TGA) of the samples was done using Netzsch Model STA $409 \mathrm{PC}$ with heating rate of $10^{\circ} \mathrm{C} / \mathrm{min}$ in nitrogen atmosphere. Dynamic mechanical analysis (DMA) was performed using Netzsch (DMA 242C) dynamic mechanical analyzer in the three-point bending mode at a frequency of $10 \mathrm{~Hz}$ and amplitude of $120 \mu \mathrm{m}$ over the temperature range of $20-180{ }^{\circ} \mathrm{C}$ at a heating rate of $2^{\circ} \mathrm{C} / \mathrm{min}$.

\section{RESULTS AND DISCUSSION}

\section{1. Flexural properties}

Results of the variation of flexural strength and flexural modulus of composites with filler content are shown in Figure 1. The flexural strength of epoxy filled Wallostonite and S2 glass fiber composites increased up to $3 \mathrm{gm}$ of Wallostonite powder (145.78-3.53 MPa). The increase in strength is mainly due to good filler matrix interaction, which is due to platy nature of the fillers. Platy filler have high aspect ratio and this increase the wet ability of the fillers by the matrix, thus creating fewer micro voids between the filler and the matrix. The Wallostonite powder, which has a higher surface area due to its small particle size, tends to agglomerate and this result in the reduction of surface interaction between the epoxy and Wallostonite. This explains the reduction in the flexural strength of Wallostonite powder filled epoxy composites ( $>3 \mathrm{gm}$ of Wallostonite) at higher filler loading $[7,10,12,18]$. 


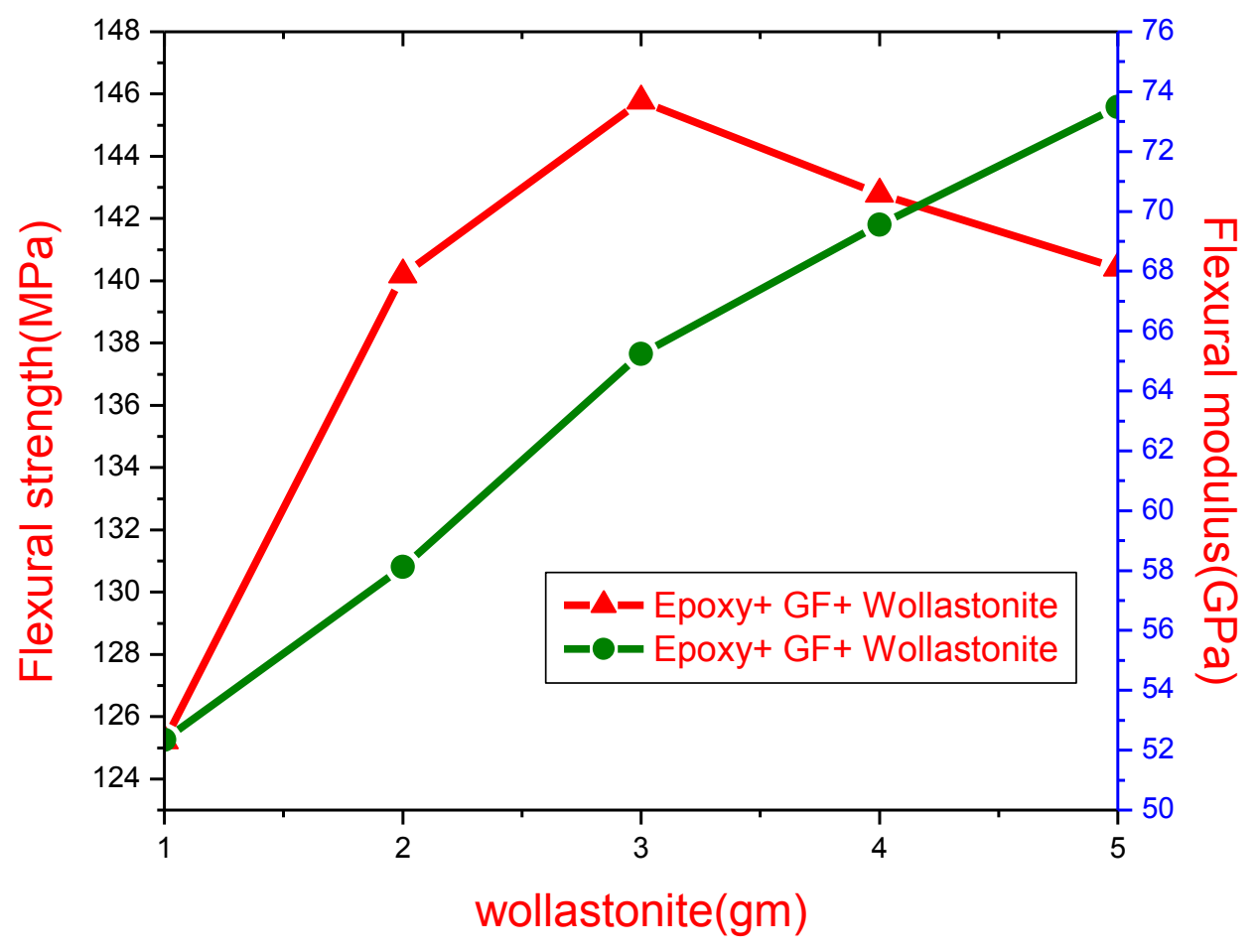

Fig. 1. Flexural strength and Flexural modulus variations for different proportions of composites.

Table 1. Flexural properties of different proportions of Epoxy filled Wallostonite and S2 - Glass fiber reinforced hybrid composites.

\begin{tabular}{|c|c|c|}
\hline Name of the sample & Flexural strength MPa & Flexural modulus GPa \\
\hline $\begin{array}{l}\text { Epoxy }(50 \mathrm{gm})+\text { Wallostonite } \\
(1 \mathrm{gm})+\mathrm{S} 2 \text {-glass fiber }(2 \mathrm{gm})\end{array}$ & $125.23+/-1.34$ & $52.34+/-2.37$ \\
\hline $\begin{array}{l}\text { Epoxy }(50 \mathrm{gm})+\text { Wallostonite } \\
(2 \mathrm{gm})+\mathrm{S} 2 \text {-glass fiber }(2 \mathrm{gm})\end{array}$ & $40.19+/-2.82$ & $58.12+/-1.22$ \\
\hline $\begin{array}{l}\text { Epoxy }(50 \mathrm{gm})+\text { Wallostonite } \\
(3 \mathrm{gm})+\mathrm{S} 2 \text {-glass fiber }(2 \mathrm{gm})\end{array}$ & $145.78+/-3.53$ & $65.24+/-2.56$ \\
\hline $\begin{array}{l}\text { Epoxy }(50 \mathrm{gm})+\text { Wallostonite } \\
(4 \mathrm{gm})+\text { S2-glass fiber }(2 \mathrm{gm})\end{array}$ & $142.78+/-1.34$ & $69.56+/-1.43$ \\
\hline $\begin{array}{l}\text { Epoxy }(50 \mathrm{gm})+\text { Wallostonite } \\
(5 \mathrm{gm})+\mathrm{S} 2 \text {-glass fibe } \mathrm{r}(2 \mathrm{gm})\end{array}$ & $140.41+/-1.59$ & $73.48+/-1.25$ \\
\hline
\end{tabular}


The variation of flexural modulus of Wallostonite in epoxy is shown in the Figure 1. Flexural modulus of Wallostonite is 50GPa. Progressive increase of Wallostonite content in epoxy resin progressive progressively increases the flexural modulus.

Flexural modulus of all types of the composite studied are found to increase linearly with increasing filler content in the matrix, indicating the positive toughening effect. The increased modulus is due to the presence of dispersed rigid particles.

The presence of Wallostonite particles might have stiffened the matrix inducing the increase observed in the modulus. It was assumed, that the space between the Wallostonite particles was filled with the matrix minimizing the presence of voids and bubbles consequently leading to increase in modulus $[19,25]$.

\section{2. Tensile Properties}

The tensile strength and tensile modulus of the different composites investigated are shown in the Figure 2. Pure Epoxy shows the tensile strength of $22 \mathrm{MPa}$. The tensile strength of Wallostonite powder filled epoxy was shown in the Table 2.

The tensile strength of Epoxy composites increase with the Wallostonite content up to 4 gm and on further addition of Wallostonite powder $(>4 \mathrm{gm})$ the tensile strength decreases. The improvement in tensile strength is caused due to limited mechanical restraint and the filler particle size. The decrease in the ultimate tensile strength is due to improper wetting of Wallostonite powder at higher filler content [28,39].

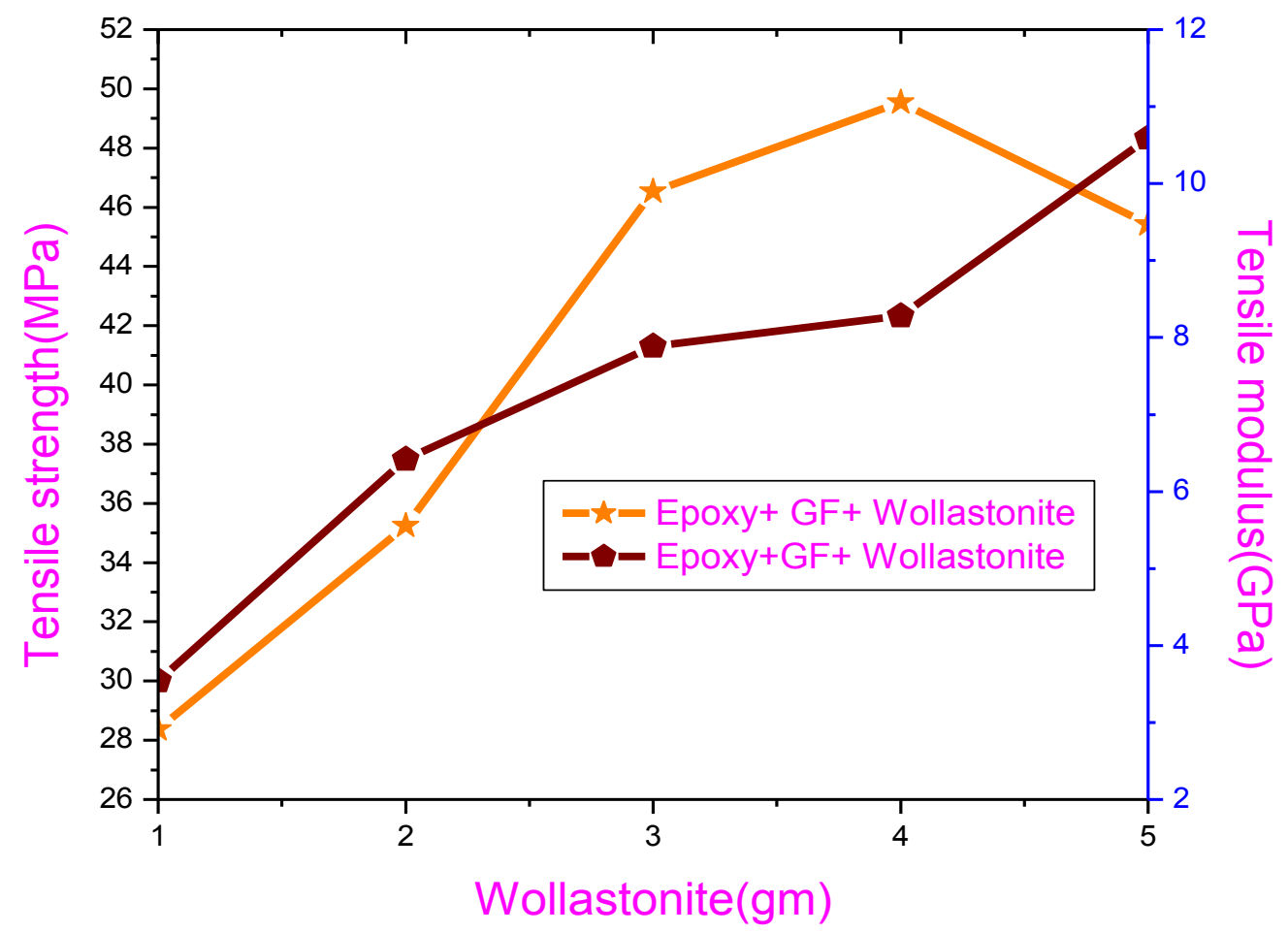

Fig. 2 Tensile Strength and Tensile modulus variations for different specimens of composites. 
Table 2. Tensile Strength and Tensile modulus for different specimens.

\begin{tabular}{|c|c|c|}
\hline Name of the sample & Tensile strength MPa & Tensile modulus GPa \\
\hline $\begin{array}{c}\text { Epoxy (50gm) + Wallostonite } \\
(1 \mathrm{gm})+\text { S2-glass fiber (2gm) }\end{array}$ & $28.37+/-1.07$ & $3.54+/-1.54$ \\
\hline $\begin{array}{c}\text { Epoxy (50gm) + Wallostonite } \\
(2 \mathrm{gm})+\text { S2-glass fiber (2gm) }\end{array}$ & $35.25+/-2.88$ & $6.42+/-0.67$ \\
\hline $\begin{array}{c}\text { Epoxy (50gm) + Wallostonite } \\
(3 g m)+\text { S2-glass fiber (2gm) }\end{array}$ & $46.54+/-3.21$ & $7.89+/-0.59$ \\
\hline $\begin{array}{c}\text { Epoxy (50gm) + Wallostonite } \\
(4 g m)+\text { S2-glass fiber (2gm) }\end{array}$ & $49.54+/-1.44$ & $10.59+/-0.29$ \\
\hline $\begin{array}{c}\text { Epoxy (50gm) + Wallostonite } \\
(5 g m)+\text { S2-glass fiber (2gm) }\end{array}$ & $45.43+/-1.89$ & 8.32 \\
\hline
\end{tabular}

Filler may enhance or deteriorate the impact properties of composites. Impact strength is an indication of tolerability for a sudden impact. When a composite is subjected to an impact, rapid crack propagation is initiated through the material. Improvement in impact strength is due to the limited cross linked network structure of the cured resin.

The Wallostonite powder particle is tracer to move within the matrix and correspondingly, the matrix is free to stretch around particles. The stress transfer rate becomes very low, which leads to a lowest impact strength. In the filled composites, as filler loading increases the tendency of agglomerates also increase, interfacial adhesion becomes weaker leading to the weaker interfacial region. These agglomerates then acts as strength concentration points or crack initiation sites. Therefore reduction in the impact strength with increasing filler content is expected.

\section{3. Thermal Analysis}

\section{3. 1. Differential Scanning Calorimetric (DSC)}

The DSC test is carried out to find the glass transition temperature of different composites. Glass Transition temperature $\left(\mathrm{T}_{\mathrm{g}}\right)$ of composites increase with increase in Wallostonite powder in the Epoxy matrix. The glass transition temperature is more for $5 \mathrm{gm}$ Wallostonite filled composite. The variation of glass transition temperature for different composites is shown in the Figure 4.

\section{3. 2. Thermo Gravimetric Analysis (TGA)}

Thermo gravimetric analysis (TGA) of the samples was done using Netzsch Model STA $409 \mathrm{PC}$ with heating rate of $10^{\circ} \mathrm{C} / \mathrm{min}$ in nitrogen atmosphere. Dynamic mechanical analysis (DMA) was performed using Netzsch (DMA 242C) dynamic mechanical analyzer in the three-point bending mode at a frequency of $10 \mathrm{~Hz}$ and amplitude of $120 \mu \mathrm{m}$ over the temperature range of $20-180{ }^{\circ} \mathrm{C}$ at a heating rate of $2{ }^{\circ} \mathrm{C} / \mathrm{min}[12,18]$. 




Fig. 3. Impact strength variation of various composites.

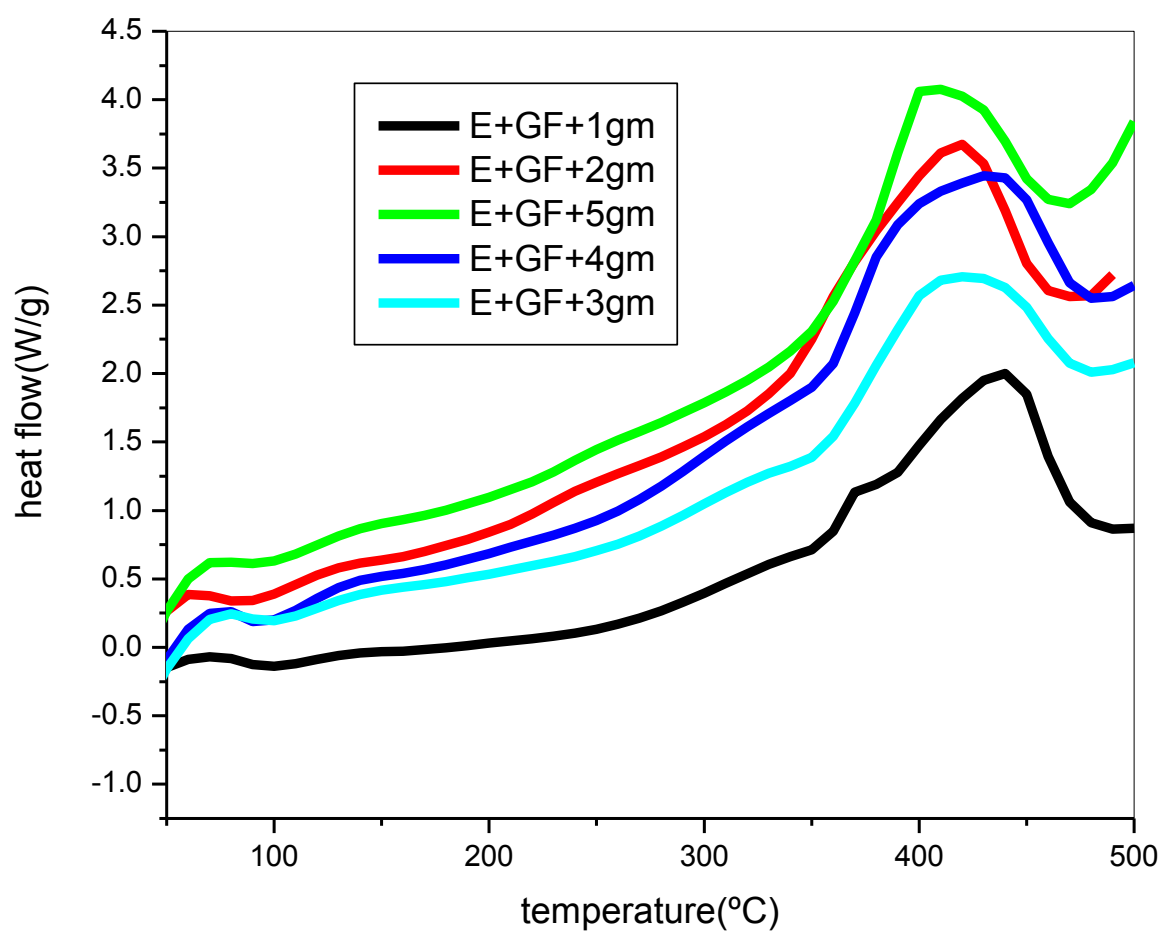

Fig. 4 Graph showing the Glass transition temperature for different composites. 


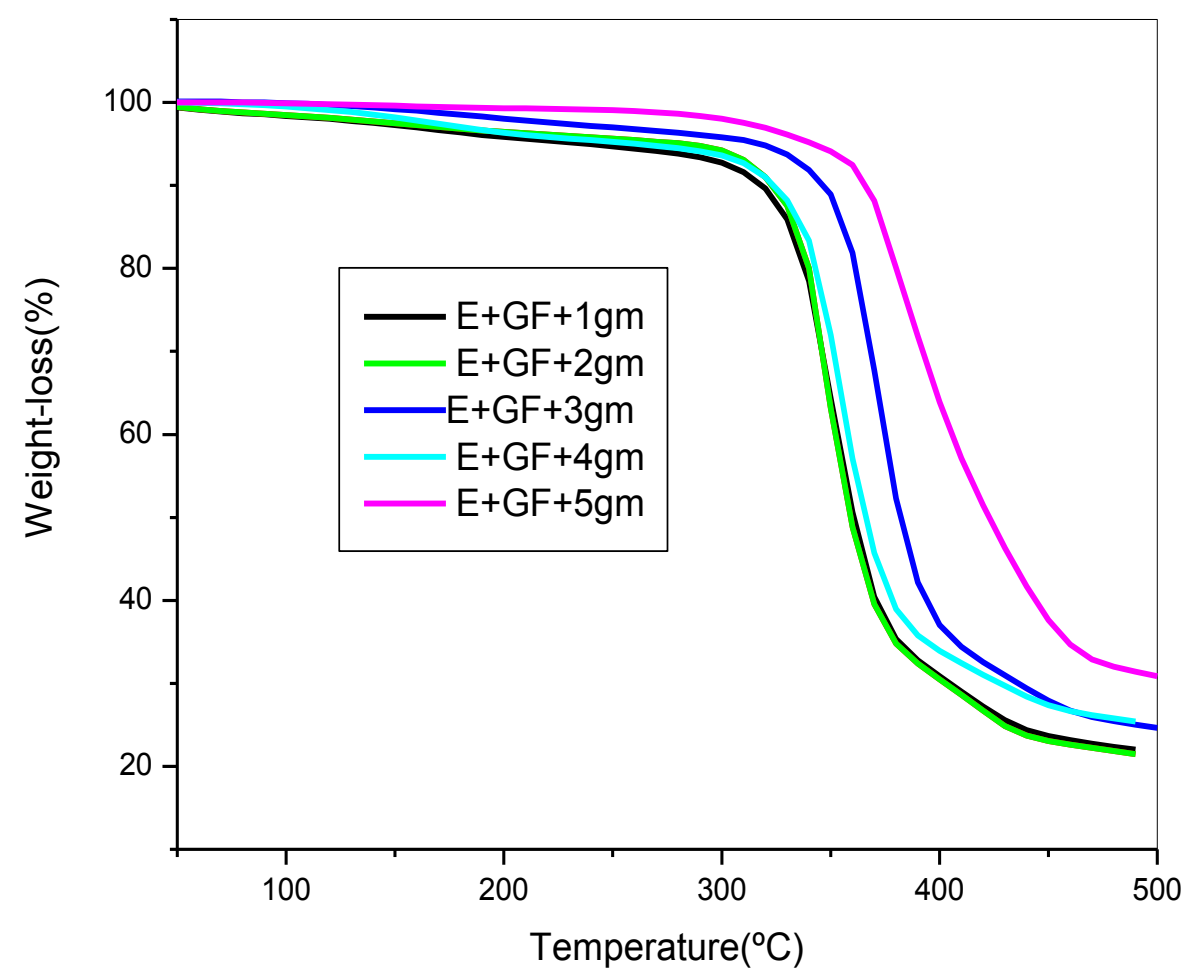

Fig. 5. Thermo Gravimetric Analysis for different composites.

Table 3. Impact strength of for various specimens.

\begin{tabular}{|l|c|}
\hline \multicolumn{1}{|c|}{ Name of the sample } & Impact strength J/m \\
\hline Epoxy (50gm) + Wallostonite (1gm) + S2-glass fiber (2gm) & $29.08+/-1.09$ \\
\hline Epoxy (50gm) + Wallostonite (2gm) + S2-glass fiber (2gm) & $40.59+/-0.86$ \\
\hline Epoxy (50gm) + Wallostonite (3gm) + S2-glass fiber (2gm) & $46.32+/-0.58$ \\
\hline Epoxy (50gm) + Wallostonite (4gm) + S2-glass fiber (2gm) & $42.82+/-0.79$ \\
\hline Epoxy (50gm) + Wallostonite (5gm) + S2-glass fiber (2gm) & $41.42+/-0.58$ \\
\hline
\end{tabular}

Thermo gravimetric curves of Epoxy filled S2 glass fiber and different amounts of Wallostonite is shown in the Figure 5. From these curves, maximum weight loss temperature for the different composites can be studied. From the figures it is very clear that Wallostonite filler allows more heat to flow. Increase in the Wallostonite filler in the composites provides good thermal stability to the materials. 


\section{CONCLUSION}

Quasi-isotropic glass fiber reinforced and Wallostonite filled epoxy hybrid composites were developed and tested for mechanical and thermal properties. Wallostonite was dispersed in to the matrix with various proportion such as 1,2, 3, 4, 5 gm by keeping glass fiber as a constant. Due to less moisture content and more metallic nature particle was attributed the improved thermal stability for 5 gms Wallostonite filled epoxy hybrid composites. Thermal stability as increased for the same sample up to $50{ }^{\circ} \mathrm{C}$ when compared with the $1 \mathrm{gm}$ Wallostonite filled composites. It was observed in the DSC analysis that due to increased viscosity of the specimen at $5 \mathrm{gm}$ as a result of that decreased glass transition temperature was observed when compared with 4gm Wallostonite filled composites. Tensile and flexural modulus was increased linearly due increased ductility. Impact strength was increased up to $3 \mathrm{gm}$ after that it was started getting down. On other hand flexural strength was optimized at $3 \mathrm{gm}$ whereas at $4 \mathrm{gm}$ tensile strength was optimized. These types of composites can be used fuel tanks, automobile and airplane bodies for fuel economy.

\section{Acknowledgments}

We would like to thank for Department of material science, IISc Bangalore, Polymer Science \& Technology Department, Sri Krishnadevaraya University, Anantapur, G. Pulla Reddy College of Engineering, Kurnool, and R V College of Engineering, Bangalore for providing laboratory facilities.

\section{References}

[1] Ashok Kumar, M., Ramachandra Reddy, G., Ramesh, A., Nanjunda Reddy, BH., Vishnu Mahesh, K.R., Sanjeev Kumar, P. 2012. Performance of coconut shell particulate filled polyester composites. Pakistan Journal Scientific Industrial Research Scr. A Phys. Sci., 55(3): 142-148.

[2] Ashok Kumar, M., Hemachandra Reddy, K., Mohana Reddy, Y.V., Ramachandra Reddy, G., Venkata Naidu, S.2010. Improvement of tensile and flexural properties in epoxy/clay nanocomposites reinforced with weave glass fiber reel. International Journal of Polymeric Materials, 59: 854-862.

[3] Borum-Nicholas, L., Wilson Jr. O.C.2003. Surface modification of hydroxyapatite. Part I. Dodecyl alcohol. Biomaterials, 24: 3671-3679.

[4] Barral, L., Cano, J., Lopez, J., Lopez-Bueno, I., Nogueira, P., Ramirez, C. 2000. Thermal properties of amine cured diglycidyl ether of bisphenol a epoxy blended with poly(ether imide). Thermochim. Acta., 344: 137-143.

[5] Boccaccini, A.R., Maque,t V.2003. Bioresorbable and bioactive polymer- Bioglasss composites withtailored pore structure for tissue engineering applications. Compos. Sci. Technol., 63: 2417-2429.

[6] Choi, D., Marra, K.G., Kumta, P.N.2004. Chemical synthesis of hydroxyapatite/ Poly(_caprolactone) composites. Mater. Res. Bull., 39: 417-432.

[7] Calandrelli, L., Immirzi, B., Malinconico, M., Volpe, M.G., Oliva, A., Della Ragione, F.2000. Preparation and characterisation of composites based on biodegradable polymers for "in vivo" application. Polymer, 41: 8027-8033. 
[8] Chakradhar, K.V.P., Venkata Subbaiah, K., Ashok Kumar, M., Ramachandra Reddy, G.2011. Epoxy/polyester blend nanocomposites: effect of nanoclay on mechanical, thermal and morphological properties. Malaysian Polymer Journal, 6(2): 109-118.

[9] Fu, J.F., Shi, L.Y., Zhang, D.S., Zhong, Q.D., Chen, Y.2010. Effect of nanoparticles on the performance of thermally conductive epoxy adhesives. Polym. Eng. Sci., 50: 18091819.

[10] Guo, J., Han-Xiong, H., Zhao-Ke, C.. Polymer Plastic Technology and Engineeing, 50(10) (2011) 1035-1039.

[11] Hari Sankar, P., Hemacahndra Reddy, K., Mohana Reddy, Y.V., Ashok Kumar, M. Development \& characterization of hybrid natural fiber reinforced polymer blended composites, International Letters of Natural Sciences 3 (2014) 7-13.

[12] Liu, Q., Van Blitterswijk, C.A. 1997. A study on the grafting reaction of isocyanates withh ydroxyapatite particles. J. Biomed. Mater. Res., 40: 358-364.

[13] Liu, Q., De Wijn, J.R., De Groot, K., Van Blitterswijk, C.A. 1998. Surface modification of nano-apatite by grafting organic polymer. Biomaterials, 19: 1067-1072.

[14] Liu, Q., de Wijn, J.R., van Blitterswijk C.A.1998. Composite biomaterials with chemical bonding between hydroxyapatite filler particles and PEG/PBT copolymer matrix. J. Biomed. Mater. Res., 40: 490-497.

[15] Mannan, K.M., Talukder, M.A.I. 1997. Characterization of raw delignified and blenched jute fibres by study of absorption of moisture and some mechanical properties. Polym., 38: 2493-2500.

[16] Park, S.J., Kim, H.C., Lee, H.I., Suh, D.H. 2001. Thermal stability of imidized epoxy blends initiated by N-benzylpyrazinium hexafluoroantimonate salt. Macromolecules, 34: 7573-7575.

[17] Song, Z., Li, Z., Yan-Ying, W., Yi, Z., Shi-Bo, G., Yu-Bao, L. 2011. Fabrication of hydroxyapatite/ethylene-vinyl acetate/polyamide 66 composite scaffolds by the injection-molding method. Polymer Plastic Technology and Engineering, 50(10): 10471054.

[18] Varada Rajulu, A., Babu Rao, G., Lakshminarayana Reddy, R.2001. Miscibility of polycarbonate/epoxy resin in dichloromethane by viscosity, ultrasonic and refractive index methods. Journal of Polymer Materials, 23:234-240.

[19] Varada Rajulu, A., Babu Rao, G. and Lakshminarayana Reddy, R.2000. Chemical resistance and tensile properties of epoxy/polymethylmethacrylate blend coated bamboo fibres. Indian Journal of Fiber and Textile Research, 25:295-297.

[20] Varada Rajulu, A., Sanjeev Kumar, S.V., Babu Rao, G.2001. Tensile properties of glass roving's / hydroxyl terminated polyester toughened epoxy composites. Journal of Reinforced Plastics \& Composites, 22: 200-206.

[21] Varada Rajulu, A., Ganga Devi, L., Babu Rao, G.2003. Miscibility studies of epoxy/unsaturated polyester resin blend in chloroform by viscosity, ultrasonic velocity, and refractive index methods. Journal of Applied Polymer Science, 89(11): 2970-2972.

[22] Verrier, S., Blaker, J. J., Maquet, V., Hench, L.L., Boccaccini, A. R. 2004. PDLLA /Bioglasss composites for soft-tissue and hard - tissue engineering: an in vitro cell biology assessment. Biomaterials, 25: 3013-3021. 
[23] Wang, X.J., Li, Y., Wei, J., De Groot, K. 2002. Development of biomimetic nanohydroxyapatite/poly (hexamethylene adipamide) composites. Biomaterials, 23: 47874791.

[24] Wang, M., Bonfield, W. 2001. Chemically coupled hydroxyapatitepolyethylene composite: structure and properties. Biomater., 22: 1311-1320.

[25] Wang, Q.F., Shi, W.F.2006. Kinetics study of thermal decomposition of epoxy resins containing flame retardant components. Polym. Degrad. Stab., 91: 1747-1754.

[26] Raghu, K., Noorunnisa Khanam, P. and Venkata Naidu, S. (2007). Chemical Resistance Studies of Silk/Sisal Fiber-Reinforced Unsaturated Polyester-Based Hybrid Composites, Journal of Reinforced Plastics and Composites, DOI: 10.1177/0731684408097770 JRPC.

[27] John, K. and Venkata Naidu, S. (2007). Chemical Resistance of Sisal/Glass Reinforced Unsaturated Polyester Hybrid Composites, J. Rein. Plast. Comp., 26: 33-38.

[28] Padma Vathi, T. and Venkata Naidu, S. (1998). Chemical Resistance and Tensile Properties of Sisal/Glass Fibres, Indian Journal of Fibre and Textile Research, 23: 128132.

[29] Venkata Reddy, G., Shobha Rani, T., Chowdoji Rao, K. and Venkata Naidu, S. (2009). Composites Flexural, Compressive, and Interlaminar Shear Strength Properties of Kapok/Glass, Journal of Reinforced Plastics and Composites, 28: 1665-1677.

[30] G. Venkata Reddy, S. Venkata Naidu and T. Shobha Rani Impact Properties of Kapok Based Unsaturated Polyester Hybrid Composites Journal of Reinforced Plastics and Composites, 27 (2008) 1789-1804.

[31] G. Venkata Reddy, S. Venkata Naidu. Shobha Rani, Kapok/Glass Polyester Hybrid Composites: Tensile and Hardness Properties, Journal of Reinforced Plastics and Composites 27 (2008) 1775-1787.

[32] Benjamin Dauda \& S. Olutunde Oyadiji \& Prasad Potluri, Characterising Mechanical Properties of Braided and Woven Textile Composite Beams, Appl Compos Mater 16 (2009) 15-31.

[33] Ashok Kumar, M., Ramachandra Reddy, G., Siva Bharathi, Y., Venkata Naidu, S. and Naga Prasad Naidu, V. (2010). Frictional Coefficient, Hardness, Impact Strength and Chemical Resistance of Reinforced Sisal-Glass Fiber Epoxy Hybrid Composites, Journal of Composite Materials, 46(26): 3195-3202.

[34] Ashok Kumar, M., Ramachandra Reddy, G., Hemachandra Reddy, K., Venkata Mohana Reddy, Y., Ranga Reddy, P. and Subbarami Reddy, N. (2011). Fabrication and Performance of Hybrid Betel Nut (Areca catechu) Short Fibre/ Sansevieria cylindrica (Agavaceae) Polypropylene Composite, Indian Journal of Material Science 2011 (in press).

[35] Ashok Kumar, M., Hemachandra Reddy, K., Ramachandra Reddy, G., Venkata Mohana Reddy, Y. and Subbarami Reddy, N. (2010). Tensile, Thermal Properties \& Chemical Resistance of Epoxy/Hybrid Fibre Composites (Glass/Jute) Filled with Silica Powder, Indian Journal of Macromolecules, 6(2): 2010 (in press). 
[36] Mishra, S. C. and Aireddy, H. (2011). Evaluation of dielectric behavior of bio-waste reinforced polymer composite. Journal of Reinforced Plastics and Composites, 30(2): 134-141.

[37] Dani Jagadesh, Varada Rajulu, A. and Guduri, B.R. Tensile Properties of Polycarbonate-Coated Natural Fabric Hildegardia populifolia. (2008). Journal of Reinforced Plastics and Technology, 27: 1833-1838.

[38] Varada Rajulu, A. and Rama Devi, R. Compressive Properties of Ridge Gourd/Phenolic Composites and Ridge Gourd/Phenolic/Glass Hybrid Composites, Journal of Reinforced Composites \& Plastics, 26: 1657-1664.

[39] Jayaramudu, J., Obi Reddy, K., Uma Maheswari, C., Jeevan Prasad Reddy, D. and Varda Rajulu, A. (2009). Tensile Properties and Thermal Degradation Parameters of Polyalthia Cerasoides Natural Fabric Reinforcement, Journal of Reinforced Plastics and Composites, 28(18): 2177-2181.

[40] Raghavendra Rao, H.,Varada Rajulu, A., Ramachandra Reddy, G., Hemachandra Reddy, K. (2010). Flexural and Compressive Properties of Bamboo and Glass Fiberreinforced Epoxy Hybrid Composites, Journal of Reinforced Plastics and Composites, 29(10): 1446-1450.

[41] Venkata Subba Reddy, E., Varada Rajulu, A., Hemachandra Reddy, K. and Ramachandra Reddy, G. (2010). Chemical Resistance and Tensile Properties of Glass and Bamboo Fibers Reinforced Polyester Hybrid Composites, Journal of Reinforced Plastics and Composites, 29(14): 2119-2123.

[42] Sreenivasan V. S., Somasundaram S., Ravindran D., Manikandan V., Narayanasamy R., Materials \& Design 32/1 (2011) 453-461. 